\title{
Interferensi pada Multilingualisme Santri Tmi Al-Amien dan Peran KH. Moh. Marzuqi Ma'ruf dalam Ishlāh Al-Akhtha' Bahasa Arab
}

\author{
Abdul Kirom \\ Institut Dirosat Islamiyah Al-Amien Prenduan, Indonesia \\ kiromhafi@gmail.com
}

\begin{abstract}
Abstrak
Artikel ini bertujuan mendeskripsikan bentuk interferensi bahasa Arab lisan pada multilingualisme santri TMI AlAmien Prenduan dan peran KH. Mohammad Marzuqi Ma'ruf dalam memperbaiki interferensi yang dialami mereka dengan program ishalahul akhtha'. Peneliti menggunakan studi deskriptif kualitatif lapangan dengan teknik pengumpulan data berupa wawancara atas beberapa ustadz Markaz Bahasa TMI, memanfaatkan dokumen-dokumen penting yang berkaitan dengan penelitian ini, dan peneliti sendiri menjadi partisipasi aktif dalam observasi di lapangan sebagai pengajar di TMI. Hasil penelitian ini menunjukkan bahwa, pertama di kalangan santri TMI dalam menggunakan bahasa Arab terdapat interferensi morfologi, sintaksis dan interferensi budaya. Kedua, peran $\mathrm{KH}$. Mohammad Marzuqi Ma'ruf dalam memperbaiki interferensi tersebut tercermin dalam program ishalahul akhtha'yang berjalan sepanjang tahun di sana. Peran beliau juga didukung kuat dengan adanya peraturan kebahasaan yang ketat yang tercermin dalam pemberian punishment dan reward. Beliau adalah sosok yang produktif dalam berkarya, dan karya-karya beliau menjadi bahan utama dalam program ishalahul akhtha'.
\end{abstract}

Kata Kunci: interferensi, Islahul Akhtha', TMI 


\begin{abstract}
This article aims to describe the form of oral Arabic interference in the multilingualism of the students of TMI AlAmien Prenduan and role of KH. Mohammad Marzuqi Ma'ruf in correcting the interference they experienced with the ishalahul akhtha' program. The researcher used a descriptive qualitative field study with data collection techniques in the form of interviews with several TMI Language Markaz ustadz, utilizing important documents related to this research, and the researcher himself became an active participant in field observations as a teacher at TMI. The results of this study indicate that, firstly among TMI students in using Arabic there is morphological, syntactic and cultural interference. Second, the role of KH. Mohammad Marzuqi Ma'ruf in correcting the interference is reflected in the ishalaul akhtha' program which runs throughout the year there. His role is also strongly supported by the existence of strict linguistic regulations which are reflected in the provision of punishment and reward. He is a productive figure in his work, and his works become the main ingredient in the ishalaulakhtha'program.
\end{abstract}

Keywords: interferences, Islahul Akhtha', TMI

\title{
PENDAHULUAN
}

Tarbiyatul Mu'allimin Al-Islamiyah (TMI) Pondok Pesanren Al-Amien Prenduan merupakan lembaga pendidikan tingkat dasar dan menengah setara SMP-SMA berbasis mu'adalah. ${ }^{1}$ Lembaga tersebut telah memberikan perhatian yang sangat besar kepada pembelajaran bahasa Arab dan bahasa Inggris semenjak awal kali dirintisnya pada tahun $1971 .^{2}$ Bahkan dalam tesis Halimi Zuhdi ${ }^{3}$ dan disertasi Moh. Makinuddin ${ }^{4}$ diungkapkan

\footnotetext{
${ }^{1}$ Al-Amien.ac.id

2 Tim Penyusun Warkat, Jurnal Informasi Tahunan Pondok Pesantren AlAmien Prenduan Provinsi Jawa Timur (Sumenep, 2016), 10.

3 Halimi Zuhdi, Al-Biah Al-Arabiyah: Takwinuha Wa Dauriha Fi Iktisabi AlArabiyah (Malang: UIN Maliki Press, 2017).

${ }^{4}$ Mohammad Makinuddin, "Al-Biah Al-Lughawiyah Wa Taudhzifiha Fi Ta'lim Al-Lughah Al-Arabiyah” (UIN Maulana Malik Ibrahim Malang, 2017).
} 
bahwa berbicara menggunakan bahasa Arab dan Inggris di TMI Al-Amien adalah wajib hukumnya bagi semua santri dan pengurus pondok sebagai bahasa pengantar bahasa komunikasi sehari-hari.

Terdapat sebanyak 1321 santri putra dan 198 guru, ${ }^{5}$ yang semuanya berasal dari daerah yang berbeda-beda, mulai dari Sabang sampai Merauke, bahkan beberapa santri berasal dari Thailand, Malaysia, Singapura dan Brunai Darussalam. ${ }^{6}$ Alih-alih jumlah 1321 (khusus putra) itu berasal dari berbagai bahasa ibu yang berbeda-beda sesuai dengan asal daerah masing-masing.

Logika yang dapat dibangun dalam laporan jurnal ini, jika di Indonesia terdapat lebih dari 500 bahasa yang berbeda-beda yang digunakan oleh penuturnya masing-masing7, maka 1321 santri yang datang untuk belajar dari berbagai provinsi ke TMI, berarti telah membawa oleh-oleh bahasa ibu lebih dari 500 ragam bahasa. Namun hal itulah justru yang menarik perhatian untuk diteliti, sebab pada kajian sosiolinguistik ${ }^{8}$ pengalaman pemerolehan dan pembelajaran bahasa yang dialamai oleh seluruh santri tersebut selama proses pendidikan yang berlangsung di TMI pastilah tidak akan terlepas dari tergelincirnya lisan pada apa yang disebut dengan istilah

\footnotetext{
5 Wawancara dengan Khuza'ie pada tanggal 13 Oktober 2019. Di Kantor TMI Al-Amien.

6 Tim Administrasi, "SAS Sistem Administrasi Santri TMI AL-Amien Prenduan," n.d.

7 Emi Zuliana, "Analisis Campur Kode (Mixing Code) Dan Alih Kode (Code Swiching) Dalam Percakapan Bahasa Anak, Studi Pada Mahasiswa Prodi Pendidikan Bahasa Arab IAIM NU Metro Lampung," IAIM NU(n.d.).

8 Belajar bahasa Arab bagi santri TMI dapat dianggap belajar bahasa ketiga, sebab bahasa daerah yang mereka bawa dari rumah adalah bahasa ibu dan bahasa Indonesia menempati bahasa kedua, maka bahasa Arab bisa disebut bahasa ketiga.
} 
interferensi bahasa, baik dari bahasa ibu (daerah) ke dalam bahasa Arab, atau dari bahasa nasional (bahasa Indonesia) ke dalam bahasa pengantar komunikasi di TMI, khususnya pada bahasa Arab.

Akan terjadi demikian karena dengan menempuh pendidikan di TMI, secara otomatis para santri dengan latar belakang bahasa yang berbeda mereka memiliki kewajiban yang sama, yakni harus mentaati aturan pondok serta wajib berbahasa Arab sepanjang harinya selama 24 jam non-stop.

Opini tersebut peneliti bangun merujuk kepada teori linguistik bahwa setiap bahasa memiliki unsur leksikal, sintaksis, kultural dan gramatikal yang berbeda-beda. Sebagaimana pernyataan Franco Aixela dalam jurnal ilmiah Km Tri Sutrisna Agustia bahwa Interferensi bahasa merupakan proses pemasukan unsur leksikal, sintaksis, kultural dan gramatikal bahasa tertentu pada bahasa yang lain ${ }^{9}$ yang tidak mungkin bisa dihindari dalam komunikasi para multilingualisme. Dari dasar ini, interferensi terjadi dalam komunikasi seseorang "yang sedang dalam proses belajar bahasa Arab sebagai bahasa asing" merupakan suatu kewajaran. Hal itu juga disampaikan dengan jelas oleh Zaidatul Arifah dalam jurnal Metalingua UTM bahwa dalam adanya kedwibahasaan pada msayarakat akan

\footnotetext{
${ }^{9} \mathrm{Km}$ Tri Surisna Agustia, "Interferensi Bahasa Indonesia Terhadap Pemakaian Bahasa Inggris Pada Siswa Kelas VIII Sekolah Menengah Pertama," Litera 3o (2017): 101.
} 
menimbulkan interferensi penyimpangan norma kebahasaan sebab keakraban dua bahasa yang mereka gunakan. ${ }^{10}$

Perlu ditekankan kembali, bahwa, santri TMI Al-Amien Prenduan merupakan anak-anak seumuran siswa SMP-SMA "yang sedang dalam proses belajar bahasa Arab". Pada komunikasi sehari-hari mereka dalam menggunakan bahasa Arab sebagai bentuk kewajiban atas aturan pondok dan demi tujuan pendidikan, merupakan hal yang wajar apabila dalam tahapan proses pembelajaran bahasa tersebut, lisan mereka sesekali mengalami interferensi, sebab mereka memang sudah terbiasa hidup dengan bahasa ibu semenjak jauh hari sebelum mereka datang ke TMI yang lingkungannya berpotensi "diglosia" sebab seluruh santri yang bermukim di dalamnya memiliki dua variasi bahasa. ${ }^{11}$

Sementara dalam poin diskusi yang lain dari pembahasan laporan jurnal ini adalah tentang ketokohan KH. Mohammad Marzuqi Ma'ruf yang merupakan sosok guru bahasa Arab yang masyhur di kalangan santri serta alumni TMI di lembaga tersebut. Bahkan hanya beliaulah hingga detik ini yang mendapatkan predikat laqob kamus al-Munjid al-Masyi dalam masyarakat pondok. Berkat jasa besar beliau dalam pembelajaran dan pengembangan bahasa Arab di Al-Amien secara umum dan khususnya di TMI, hampir pasti tak satu pun santri yang telah menjadi alumni lembaga tersebut kecuali di

\footnotetext{
10 Zaidatul Arifah, "Interferensi Dan Integrasi Kata-Kata Daerah Dan Asing Dalam Novel 'Dian Yang Tak Kunjung Padam,'” Metalingua 5, no. Bahasa dan Sasra Indonesia (2020).

${ }^{11}$ Abdul \& Loenie Agustiana Chaer, Sosiolinguistik Perkenalan Awal (Jakarta: Rineka Cipta, 2010), 92.
} 
dalam pengetahuan bahasa Arab yang mereka dapatkan terdapat jasa beliau.

Penelitian ini memiliki beberapa kemiripan pembahasan dengan kajian-kajian terdahulu namun di dalamnya tidak terdapat kesamaan, di antaranya, pertama: atas jurnal yang ditulis oleh Muna Nabila Amatullah dan Lady Farah Azizah dengan judul interferensi bahasa Indonesia dalam bahasa Arab: kasus pada kesalahan berbahasa siswa kelas XI MAN 1 Sragen. Jurnal ini memuat laporan tentang bentuk dan jenis interferensi bahasa Indonesia dalam bahasa Arab, baik dari sisi fonologi, morfologi dan sintaksis, ${ }^{12}$ sementara dalam penelitian yang peneliti angkat tidak hanya berfokus pada interferensi bahasa Indonesia ke dalam bahasa Arab, melainkan juga dalam interferensi bahasa daerah dan bahasa Indonesia dalam pembelajaran bahasa Arab. Kedua: laporan jurnal Muhamad Arif Mustofa yang berjudul interferensi bahasa Indonesia terhadap bahasa Arab (analisis interferensi dalam pembelajaran maharah kalam), yang memuat laporan tentang bentuk dan faktor terjadinya interfernsi bahasa Indonesia dalam kalam bahasa Arab mahasiswa PBA IAIN Curup. ${ }^{13}$ Namun penelitian ini tidak membahas bagaimana interferensi itu dapat diperbaiki. Sementara yang akan dikaji dalam artikel ini adalah dengan objek kajian di TMI Al-Amien Prenduan dan tidak hanya membahas

12 Muna Nabila Amatullah and Lady Farah Aziza, "Interferensi Bahasa Indonesia Dalam Bahasa Arab: Kasus Pada Kesalahan Berbahasa Siswa Kelas X Man 1 Sragen," ALSUNIYAT: Jurnal Penelitian Bahasa, Sastra, dan Budaya Arab 3, no. 1 (2020): 47-60.

13 Muhamad Arif Mustofa, "Interferensi Bahasa Indonesia Terhadap Bahasa Arab (Analisis Interferensi Dalam Pembelajaran Maharah Kalam)," Jurnal AnNabighoh 20, no. 2 (2018): 139-160. 
bentuk interferensi yang terjadi, melainkan juga membahas lebih lanjut terhadap perbaikan yang dilakukan di tempat tersebut dan oleh siapa.

Maka dari beberapa paparan di atas, terdapat beberapa tujuan dari adanya penelitian ini, yang antara lain adalah untuk mendeskripsikan beberapa bentuk interferensi bahasa Arab lisan pada multilingualisme santri TMI Al-Amien Prenduan serta mendeskripsikan peran KH. Mohammad Marzuqi Ma'ruf dalam memperbaiki interferensi bahasa Arab para santri dalam program islahul akhtha'.

\section{METODE PENELITIAN}

Dalam penelitian ini, peneliti menggunakan studi kualitatif ${ }^{14}$ lapangan ${ }^{15}$ dengan mendeskripsikan secara langsung tentang bentuk-bentuk interferensi bahasa lain dalam penggunaan bahasa Arab lisan santri TMI Al-Amien Prenduan, serta peran KH. Mohammad Marzuqi Ma'ruf dalam memperbaiki interferensi tersebut dengan teknik pengumpulan data berupa wawancara atas beberapa ustadz Markaz Bahasa TMI, serta memanfaatkan dokumen-dokument penting yang berkaitan dengan penelitian ini semisal dokumentasi pelanggaran bahasa yang disengaja oleh santri dilakukan dalam menginterferensi bahasa, kemudian peneliti sendiri menjadi partisipasi aktif dalam observasi di lapangan sebagai pengajar di TMI. Setelah data

\footnotetext{
14 Lexi J Moleng, Metodologi Penelitian Kualitatif (Bandung: Remaja Rosda Karya, 2009), 6.

15 Muhammad Rusli, Pedoman Praktis Membuat Proposal Dan Laporan Penelitian Lapangan (Sumenep: LP3M Paramadani, 2013), 143.
} 
terkumpul, selanjutnya dianalisis dengan tiga langkah, yaitu reduksi data, penyajian data dan penarikan kesimpulan. Terakhir dengan triangulasi sumber sebagai pengecekan keabsahan data.

\section{HASIL DAN PEMBAHASAN}

Semenjak dahulu bahasa Arab santri TMI Al-Amien seringkali mendapatkan "pujian positif" dari berbagai kalangan, terutama dalam even-even debat bahasa Arab dan even-even bahasa Arab lainnya di berbagai kampus dan pesantren. Dua di antaranya, pertama oleh ketua Mudir Markaz Bahasa UNIDA Gontor Ust. Dr. Abdul Hafidz Zaid saat beliau menjadi juri lomba debat bahasa Arab di UNIDA Gontor dengan tema Mahrajan 'Alam Araby pada 26-29 september 2014 silam. ${ }^{16}$ Pujian lainnya juga disampaikan oleh salah seorang TIM dewan juri bernama Ummi Ubaida dalam lomba debat bahasa Arab Ihtifal Institusi Pengajian Tinggi ASEAN pada 1 April 2018 di USIM Malaysia. ${ }^{17}$

Namun tentu saja di balik berbagai pujian itu, sebelum bahasa Arab mereka menjadi baik, para santri TMI sudah melewati berbagai proses pendidikan ishlahul akhtha'yang tidak instan, yang beratus-ratus kali mereka lalui demi mencapai target steril dari interferensi bahasa lainnya dalam berkomunikasi dengan menggunakan bahasa Arab, yang dari sana akhirnya mereka sudah terbiasa, terbentur dan kemudian terbentuk, menjadi siap dan matang.

\footnotetext{
16 Wawancara dengan Abdul Hakim (santri TMI Al-Amien yang sering mendapatkan juara dalam lomba-lomba Bahasa Arab) pada tanggal 22 Desember 2019 di PP. Al-Amien Prenduan

17 Wawancara pribadi dengan Firdaus pada tanggal 18 November 2018 di PP. Al-Amien Prenduan
} 
Berikut ini peneliti paparkan data-data yang peneliti temukan khusunya data yang berhubungan dengan bentukbentuk interferensi bahasa yang dominan terjadi dalam komunikasi bahasa Arab santri dan peran KH. Moh. Marzuqi dalam islahul akhtha' interferensi bahasa Arab lisan santri TMI AL-Amien Prenduan sebagaimana berikut:

\section{Bentuk-Bentuk Interferensi Bahasa yang Dominan Terjadi dalam Komunikasi Bahasa Arab Santri TMI Al-Amien Prenduan}

Dari sekian banyak bentuk interferensi bahasa yang seringkali ditemukan dalam ujaran penutur pada masyarakat dwi bahasa dan multilingual, dalam penelitian ini di TMI Al-Amien Prenduan hanya terdapat tiga bentuk interferensi saja, sebagaimana berikut:

a. Interferensi Morfologi (Morphological Interference)

Interferensi morfologi (morphological interference) ini kerap terjadi pada bentuk dasar bahasa pertama bahasa anak (bahasa Indonesia) dengan pembumbuhan afiks pada bahasa kedua (bahasa Arab) yang sedang mereka pelajari. ${ }^{18}$ Adapun bentuk afiksasi yang dimasukkan ke dalam bahasa kedua dari bahasa pertama di sini berupa akhiran atau sufiks /an/.

Sebagaimana data yang peneliti dapatkan dari Markaz Lughah Al-Amien Prenduan bahwa bentuk interferensi

\footnotetext{
18 Suindratini and Dkk, "Interferensi Bahasa Bali Dan Bahasa Asing Dalam Cerita Lisan Bahasa Indonesia Kelas VII Siswa SMP Negeri 10 Denpasar," Jurnal Program Pascasarjana Universitas Pendidikan Ghanesha Program Pendidikan Ghanesa Program Studi Pendidikan dan Sastra Indonesia 2 (2013): 5.
} 
morfologi yang biasa dialami oleh santri TMI Al-Amien Prenduan saat mereka berbicara menggunakan bahasa Arab

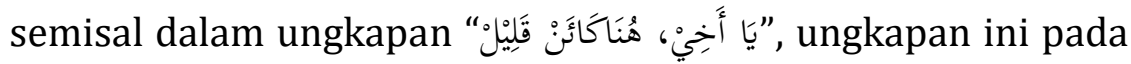
dasarnya mengandung morfologi bahasa Indonesia yang biasanya digunakan oleh penutur aslinya dalam ungkapan "Bro, kesanaan dikit dong". Sementara itu, ungkapan kalimat “畺”, justru tidak dikenal maksud yang diinginkan, sebab untuk meminta seorang kawan agar menggeser tempat duduknya agar lebih diperluas lagi dalam

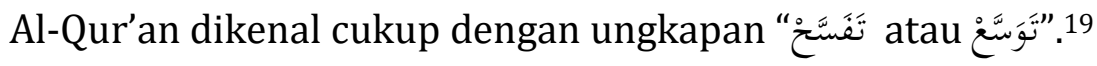

Kata هُ هُ هَنَكَ memiliki makna di sana, semenara kata memiliki makna ke, walhasil, kalimat إِلَ هُنَاكَ yang memiliki makna "ke sana" digunakan dalam komunikasi sehari-hari oleh masyarakat Indonesia pada umumnya untuk menunjukkan atas makna yang sama, yakni: /di sana/, /di situ/, /ke situ/ dan kemudian ditambah sufiks /an (نَّن / yang biasanya digunakan dalam bahasa komunikasi sehari-hari masyarakat Indonesia dan secara khusus masyarakat Madura dalam percakapan non formal.

Any Budiarti mengutip pendapat beberapa tokoh linguistik seperti Hartaman, Stork, Chaer, Agustiana, Lado, Hammers dan Blanc menyatakan bahwa "Interferensi dapat terjadi juga karena terbawanya kebiasaan-kebiasaan ujaran 
bahasa pertama atau bahasa ibu ke dalam bahasa kedua". ${ }^{20}$ pengimbuhan sufiks /an $(\dot{\mathcal{u}}) /$ ini sebetulnya salah, namun wajar terjadi dalam komunikasi seseorang yang sedang mempelajari bahasa kedua.

Selain kalimat di atas yang peneliti dapatkan dari Markaz Bahasa TMI masih terdapat beberapa kalimat bahasa Arab lainnya yang bertambah sufiks /an/ yang sering digunakan oleh beberapa santri dalam komunikasi mereka ketika berbicara menggunakan bahasa Arab, antara lain sebagaimana data dalam tabel berikut:

\begin{tabular}{|c|c|}
\hline $\begin{array}{l}\text { Arti dalam bahasa } \\
\text { Indonesia }\end{array}$ & $\begin{array}{c}\text { Kata bahasa Arab yang } \\
\text { terinterferensi morfologi } \\
\text { sufiks /an/ }\end{array}$ \\
\hline Kedepanan & تَقَََََّمَانْ قَلِيلْنْ \\
\hline Kebelakangan & تَوَرَّرَانْ فَلِيْْْْ \\
\hline $\begin{array}{l}\text { Bes-abesen (ngapain kamu } \\
\text { lihat-lihat) }\end{array}$ & 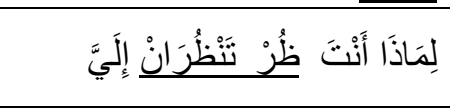 \\
\hline
\end{tabular}

b. Interferensi sintaksis (Cyntactic Interference)

Interferensi sintaksis juga disebut interferensi gramatikal. $^{21}$ Interferensi ini terjadi saat santri berbicara menggunakan bahasa Arab namun dengan menggunakan susunan OSP bahasa ibu atau bahasa Indonesia.

\footnotetext{
${ }^{20}$ Any Bundiarti, "Interferensi Bahasa Indonesia Ke Dalam Bahasa Inggris Pada Abstrak Jurnal Ilmiah," Jurnal Bahasa dan Seni 41, no. 1 (2013): 12.

21 Endang Fauziati, "Interferensi Gramatikal Bahasa Indonesia Dalam Bahasa Inggris: Kasus Pada Buku LKS Bahasa Inggris Untuk SLTP Di Surakarta," Jurnal Penelitian Humaniora 17, no. 2 (2016): 101.
} 
Sebagai contoh, ada beberapa jumlah kalimat bahasa Arab yang diucapkan santri yang tidak dikenal maksudnya dalam bahasa Arab, di antaranya “أَنْتَ هَذَا مَوْجُوْدُ مَوْجُجودُ فَفَطْ ". Yang pada hakikatnya, ungkapan yang demikian dari segi susunan gramatikalnya tidak pernah dikenal dalam bahasa Arab. Sebab utama mengapa santri mengungkapkan hal tersebut dalam komunikasi mereka adalah karena ia menterjemah kataperkata yang kemudian dirangkai dalam kalimat lengkap yang sebetulnya ingin dimaknai "kamu ini ada-ada saja", sementara

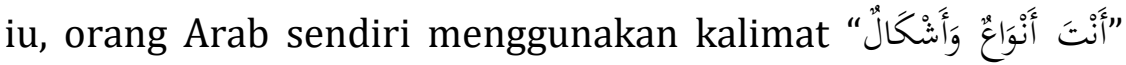
untuk mengungkapkan kalimat "kamu ini ada-ada saja", hanya saja beberapa santri yang terjebak dalam interferensi sintaksis ini karena mereka tidak mengetahui ungkapan yang biasa digunakan oleh orang Arab itu sendiri.

Selain kalimat bahasa dalam bahasa Arab di atas, berdasarkan data yang dimiliki oleh Markaz Bahasa Al-Amien masih terdapat beberapa ungkapan lagi yang biasa digunakan oleh santri yang di antaranya:

\begin{tabular}{|c|c|}
\hline Arti kalimat & $\begin{array}{l}\text { Kalimat bahasa Arab yang } \\
\text { terinterferensi sintaksis bahasa } \\
\text { Indonesia }\end{array}$ \\
\hline $\begin{array}{l}\text { Jangan lama-lama di } \\
\text { kamar mandi }\end{array}$ & 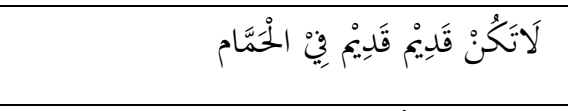 \\
\hline $\begin{array}{l}\text { Kenapa nggak ada ustadz } \\
\text { sekarang? }\end{array}$ & 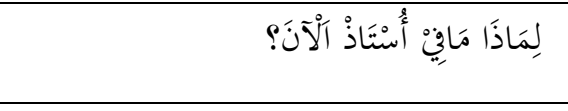 \\
\hline Eh..., pukul belnya & إِيْ .... إِضْرِبْ جَرَسن \\
\hline Apakah ada yang masuk? & 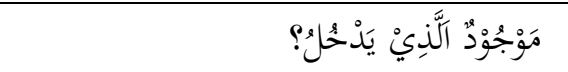 \\
\hline $\begin{array}{l}\text { Siapa yang punya sampo } \\
\text { ey. }\end{array}$ & مَنْ يُوْجَدْ سَامْبْوُ إِيْ \\
\hline
\end{tabular}




\begin{tabular}{|c|c|}
\hline Khatibnya kurang fasih & الخَطِيْبُ نَاِقصُ فَصِيْحِ \\
\hline Saya anggota (kamar) sini & أَنَا أَعْضَاءُ هُنًَا \\
\hline
\end{tabular}

c. Inteferensi Budaya

Interferensi budaya ini terjadi saat seorang penutur gagal menerjemahkan bahasa pertama ke dalam bahasa kedua atau bahasa target. ${ }^{22}$ Artinya, istilah-istilah atau kosa kata yang terdapat pada bahasa target terinterferensi oleh makna bahasa pertama. ${ }^{23}$ Lebih jelasnya, ketika seorang penutur menggunakan bahasa target namun secara teoritis memaknainya dengan bahasa pertama, itu lah interferensi budaya menurut Mohammad Ali al-Khulli. ${ }^{24}$

Berdasarkan data yang diberikan oleh Anggota Markaz Bahasa Al-Amien, Qomarul Layali, sekurang-kurangnya terdapat dua bentuk interferensi budaya yang unik di kalangan santri TMI ini. Pertama, interferensi budaya yang diucapkan secara sengaja, dengan modus, bahasa yang diujarkan dalam interferensi budaya ini sebagai bahan

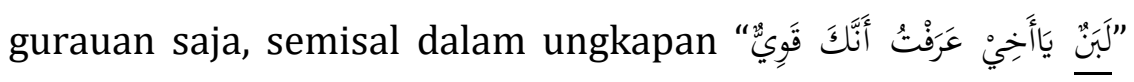
yang jika ditarjamahkan ke dalam bahasa Indonesia memiliki arti kurang-lebih "Laben kawan, saya tahu bahwa kamu kuat". Kata laban (لَ) young terdapat dalam bahasa Arab ini juga

\footnotetext{
${ }^{22}$ Agustia, "Interferensi Bahasa Indonesia Terhadap Pemakaian Bahasa Inggris Pada Siswa Kelas VIII Sekolah Menengah Pertama," 104.

23 Mohammad Afifudin Dimyathi, Madkhal Ila 'Ilmi Al-Lughah (Malang: Makabah Lisan Arabi, 2016), 88.

${ }^{24}$ Ali Mohammad Al-Khuli, Madkhal Ila Ilmi Al-Lughah (Ordon: Dar al Falah, 1993), 209.
} 
ditemukan dalam bahasa Madura dengan makna yang berbeda. Pada bahasa Arab kata tersebut bermakna "susu", sementara dalam bahasa Madura ia bermakna "lawan". 25

Kasus yang biasa terjadi adalah, para santri posisinya sedang berbicara antara satu dengan yang lain dengan menggunakan bahasa Arab namun arti yang mereka inginkan adalah arti bahasa Madura dengan menggunakan kosa kata yang sama. Sama-sama dikenal dalam bahasa Arab dan bahasa Madura.

Adapun bentuk interferensi budaya lainnya juga yang sering terjadi ialah persis seperti yang disampaikan ahli linguistik bernama Mohammad Ali al-Khulli di atas, yakni ketika terdapat seorang santri menggunakan bahasa target namun secara teoritis memaknainya sebagaimana yang ia dapatkan dalam bahasa pertama. Semisal apa yang mereka

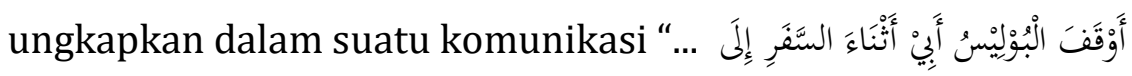

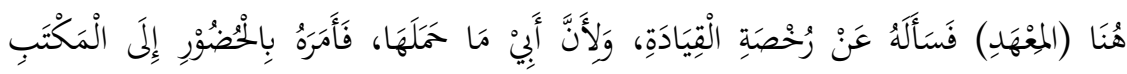

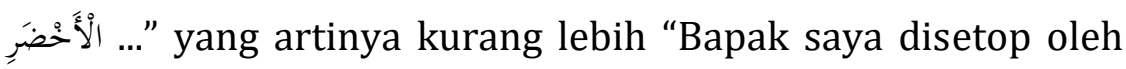
polisi saat dalam perjanan menuju ke sini (menuju ke pondok untuk mengirim saya), kemudian polisi tersebut menanyakan SIM, namun karena bapak saya sedang tidak membawanya

25 Wawancara dengan Ustadz Qomarul Layali pada tanggal 10 Februari 2020 di kantor Markaz Lughoh. 
maka polisi tersebut meminta bapak untuk hadir ke meja hijau". ${ }^{26}$

Permasalahan dalam bentuk interferensi kedua ini adalah karena si penutur dari santri tidak mengetahui istilah "meja hijau" dalam budaya Arab. Sementara pada sisi yang lain, ia mengetahui bahwa bahasa Arab dari "meja" adalah "الْمَكْتَبُ dan makna dari kata "hijau” adalah "الْغَخْضَرُ". Dengan begitu, apa yang diungkapkan oleh santri untuk menyampaikan maksud dari meja hijau adalah hasil terjamahkata-per kata. Padahal, kalimat "meja hijau" adalah ungkapan tentang sidang SIM di Mahkamah, yang seharunya kalimat itu

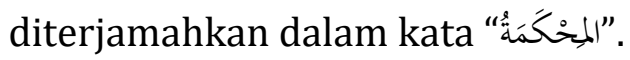

\section{Peran KH. Mohammad Marzuqi Ma'ruf dalam Islahul Akhtha' Interferensi Bahasa Arab Lisan Santri TMI Al-Amien Prenduan}

Untuk meminimalisir terjadinya interferensi bahasa dalam penggunaan bahasa Arab di TMI menurut ketua bagian Biro Pendidikan dan Kaderisasi Pondok Pesantren Al-Amien Prenduan bahwa pihaknya dalam mengupayakan hal tersebut dengan beberapa hal, dua dari sekian upaya yang ada adalah dengan memanfaatkan kunjungan-kunjungan dari tamu-tamu yang berasal dari Timur-Tengah untuk berbicara di depan seluruh santri. Kemudian upaya yang lain adalah dengan mengirimkan kader-kader terbaik Al-Amien untuk melanjutkan

\footnotetext{
${ }^{26}$ Wawancara dengan Ahmad Riyadi pada tanggal 08 Februari 2020 di TMI AlAmien.
} 
studinya di Mesir, Yaman, Sudan, Makkah, Madinah dan lainlain. ${ }^{27}$ Hal yang seperti ini sangat membantu santri untuk semakin mengenali budaya bahasa Arab dan dapat membantu peminimalisiran interferensi bahasa Arab mereka dalam beberapa bahasa lainnya, apalagi setelah para kader itu sudah menamatkan studinya dan kembali ke pondok untuk kembali mengabdikan diri.

Lebih dari pada itu, pihak pondok telah merancang sebuah program yang disebut dengan istilah Islahul Akhtha'. Istilah itu pada dasarnya merujuk pada akar kata yang berasal dari dua fi'il

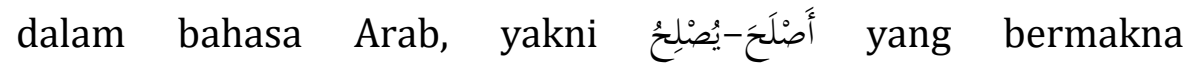
memperbaiki, dan kata خَ خَطِئَ - yang bermakna salah atau keliru.

Berangkat dari dua akar kata di atas dapat ditemukan bahwa yang dimaksud dengan istilah إصلاح الأخطاء (Islahul Akhtha) dalam makna definitifnya adalah kegiatan yang dilaksanakan untuk memperbaiki kekeliruan-kekeliruan atau kesalahan-kesalahan dalam menggunakan bahasa Arab.

Sementara salah satu SDM terbaik yang dimiliki oleh pondok dalam keberlangsungan program tersebut agar menjadi pembelajaran bahasa Arab yang dapat mengurangi bentuk interferensi bahasa dengan efektif, efisien, serta aktif dan menyenangkan bernama lengkap KH. Mohammad Marzuqi Ma'ruf. Beliau adalah tokoh katibyang terkenal di kalangan santri

27 Wawancara dengan Ustadz Suhaimi Zuhri pada tanggal 10 Februari 2020 di kantor Markaz Lughoh. 
dan alumni dengan laqob (nama panggilan) kamus Munjid berjalan dan karena beberapa karyanya dalam bidang tersebut. Beliau adalah alumni TMI angkatan perdana dengan peringkat 1. Setelah menyelesaikan studinya mulai dari tingkat bawah dan menengah di TMI selama 6 tahun menyantri, dan ditambah beberapa tahun untuk mengabdi, atas dukungan penuh dari pondok Al-Amien beliau mencoba mendaftarkan diri ke fakultas Ta'lim Lughah Arabiyah Universitas Ummul Qura Makah untuk melanjutkan kuliah dan diterima. Beliau melanjutkan kuliah dari tahun 1980 sampai 1985 M.28

Kembalinya beliau dari Ummul Qura Makkah ke Pondok Pesantren Al-Amien Prenduan, beliau menjabat sebagai penanggung jawab pembelajaran bahasa Arab di pondok tersebut, khususnya di TMI Al-Amien Prenduan Sumenep Madura. Di TMI Al-Amien Prenduan terdapat banyak sekali ragam dan bentuk pembelajaran bahasa Arab dengan banyak buku materi ajar. Selain materi ajar yang sama persis seperti pembelajaran bahasa Arab di Pondok Modern Darus Salam Gontor Ponorogo dalam kegiatan KBM, KH. Mohammad Marzuqi Ma'ruf diberikan dukungan penuh oleh pengurus Al-Amien untuk menjalankan kegiatan ishlahul Akhtha' lughawiyah Arabiyah dengan membuat buku khusus dalam program itu. 28 Wawancara dengan Ustad Izzat Amini pada tanggal 8 Oktober 2020 di
kampus IDIA Prenduan 


\section{Materi Ishlahul Akhtha'}

Materi-materi ishlahul akhtha' semuanya merupakan karya yang ditulis langsung oleh KH. Mohammad Marzuqi Ma'ruf. Setidaknya terdapat lima karya beliau yang dijadikan bahan materi dalam ishlahul akhtha' ini yang antara lain adalah: satu, Kitab Ishlahul Akhtha' Fi Usbu' al-Lughah, Kitab ini merupakan kitab yang khusus digunakan untuk materi-materi kegiatan pembukaan minggu bahasa Arab. Di dalamnya terdapat 6 kelompok kolom yang masing-masing kolom terdiri dari 5 bentuk ungkapan yang salah dan disertai 5 ungkapan yang benar di sebelahnya.

Berikut adalah contoh dari salah satu kolom yang enam

\begin{tabular}{|c|c|}
\hline العبارات والأسـاليب الصحيحـة & العبارات والأساليب المخطئة \\
\hline مَا رَأَيْتُكَكَ مِنْ زَمَانٍ & أَنَا قَدِيْمِ مَا لََقِيْتُ بِكَكَ \\
\hline أَنَا بِحَاجَاِة إِلَيْكَ & أَنَا أَحْتَاجُجُكَ \\
\hline أُرِنِنْ أَنْ أُكَلِّمَكَكَ & أُرِيْدُ أَتَكَلَّمُ مَعَكَ \\
\hline 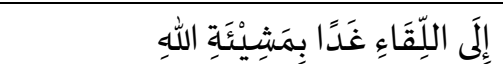 & غَدًَا أَيْضًِا نَعَمْ \\
\hline 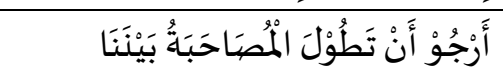 & 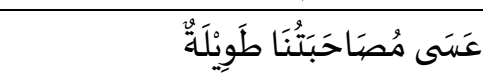 \\
\hline
\end{tabular}

Dua, Kitab Ishthilahat Wa Ishlahul Akhtha', kitab ini merupakan kitab yang paling banyak berisi ungkapan-ungkapan sebagaimana yang dikemukakan oleh penulisnya pada halaman pengantar sebagaimana berikut:

$$
\text { أفهذا الكتيب يتضمن عددا من الاصطيلاحات والأساليب الجميلة في بعض التسهيلات العامة، رجاء أن يكون هذا الإعداد مساعدة للطلبة على }
$$

29 Muhammad Marzuqi Ma'ruf, Ishlah Al-Akhtha' Fi Usbu' Al-Lughah (Sumenep: Markas Bahasa Pondok Pesantren Al-Amien Prenduan, 2019), 1. 
تزويدهم الأساليب الاصطلاحات والأساليب الجميلة التي يتعامل بها متحدثيها،

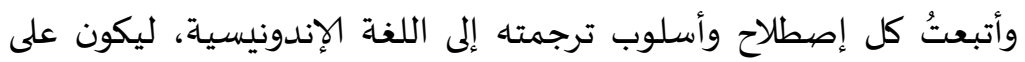

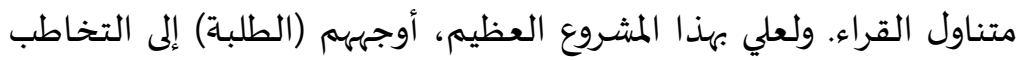

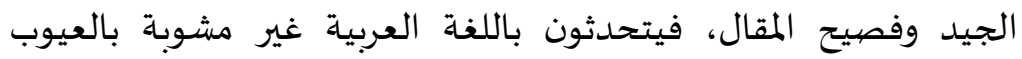

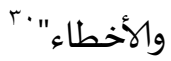

Sesuai pernyataan penulis, bahwa kitab ini terdiri atas ungkapan-ungkapan indah yang biasa digunakan di beberapa tempat. Dibuatnya kitab ini bertujuan membantu para pelajar bahasa Arab agar mereka mampu dengan mudah berkomunikasi dengan ungkapan-ungkapan indah ini. Selain itu, penulis juga menyertakan tarjamahan dalam bahasa Indonesia pada setiap ungkapan yang tertulis di dalamnya.

Kitab ini memuat kurang lebih 410 bentuk ungkapan yang indah, praktis dan steril dari bentuk interferensi bahasa lainnya. Adapun beberapa contoh ungkapan yang termuat di dalamnya antara lain sebagaimana berikut:

\begin{tabular}{|c|c|c|}
\hline Hal. & الترجمة باللغة الإندونيسية & الاصطلاحات وإصلاح الأخطاء \\
\hline$r$ & $\begin{array}{l}\text { Ini sarang laba-laba, } \\
\text { bersihkan. }\end{array}$ & هَذَا بَيْتُ الْعَنْكَبُوْتِ، نَنِظْفُُْ \\
\hline$r$ & Letakkan sepatu itu di rak & ضَع الْحِذَاََ فِيْ الرَّفِِّ \\
\hline$r$ & Kakimu kotor, ayo cuci & رِجْلُلَكَ وَسِخَةُ، إِغْسِلْهَا \\
\hline$\xi$ & Menara itu tinggi sekali & 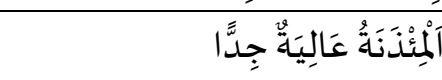 \\
\hline 0 & Awas kalau belum jera & حَذَارِ إِنْ لَمْ تَتُبْْ \\
\hline 0 & $\begin{array}{l}\text { Mentang-mentang kuat, } \\
\text { kamu mengancam } \\
\text { pelapornya }\end{array}$ & 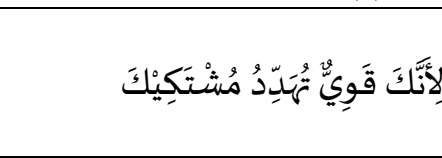 \\
\hline 0 & Hakimnya tidak adil & آلَْاكِمُ مُحَابٍ \\
\hline
\end{tabular}

${ }^{30}$ Muhammad Marzuqi Ma'ruf, Ishthilahat Wa Ishlah Al-Akhtha' Li Al-Mustawa Al Mutawassith Bi Ma'hadi Al-Amien Al-Islami Prenduan, n.d., 1. 


\begin{tabular}{|c|c|c|}
\hline $\bar{V}$ & Eh..., hemat air & 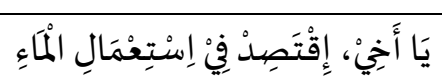 \\
\hline$\Lambda$ & Saya tidak berselera & أَنَا غَيْرُ مُشْتَتَهِه \\
\hline 9 & $\begin{array}{l}\text { Saya senang telur mata } \\
\text { sapi }\end{array}$ & أَنَا أُحِبٌُُ الْعُجََّة \\
\hline 1. & Bagus sekali buku ini & مَا أَرْوَعَ هَذَا الْكِتَابَ \\
\hline
\end{tabular}

Isi dari buku ini banyak digunakan sebagai materi dalam ujian lisan mulai dari kelas I TMI sampai kelas VI TMI yang setara SMP SMA. Adapun ujian lisan TMI diadakan sebanyak dua kali dalam setahunnya. ${ }^{31}$

Tiga, Kitab Ishthilahat as-Saya'i'ah, Sedangkan buku ketiga ini memiliki dua versi bentuk isi, yang kedua-duanya tersusun secara berselang-seling di dalam buku ini. Isi yang pertama adalah bentuk ungkapan bahasa Arab dan tarjamahannya dalam bahasa Indonesia, sedangkan bentuk yang kedua adalah ungkapan bahasa Arab yang salah dan biasa digunakan oleh santri TMI yang disertai dengan ungkapan yang benar yang telah diperbaiki oleh penulis.

Di dalamnya terdapat puluhan judul dari berbagai bentuk ungkapan sesuai dengan tempat masing-masing, seperti di Masjid, di kamar mandi, di wartel dll. Adapun sebagian dari contoh bentuk ungkapan tersebut sebagaimana berikut: ${ }^{32}$

\begin{tabular}{|c|c|}
\hline المعنى الإندونيسي & العبارات والأساليب \\
\hline Jangan membuang sisa makanan di sini & لَالَتَرِمِ فَضْلَ الطَُّعَامِ هُنَا \\
\hline
\end{tabular}

31 TIM, Proposal Ujian Syafahi TMI Al-Amien Prenduan tahun ajaran 20192020, lihat juga, Dokumentasi soal Ujian Sayfahi TMI Al-Amien Prenduan tahun ajaran 2019-2020.

32 Muhammad Marzuqi Ma'ruf, Ishthilahat Al-Saya'íah Li Al-Mustawa AlMutawassith, n.d., 3-13. 


\begin{tabular}{|c|c|}
\hline \multirow{2}{*}{$\begin{array}{l}\text { Dinding itu masih sedang dicat } \\
\text { Bunga-bunga itu menguning }\end{array}$} & آلْججدَارُ تَحْتَ التَّطْلْلِيَة \\
\hline & 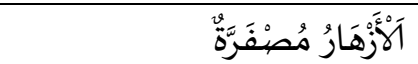 \\
\hline & إصلاح الأخطاء الشائعة \\
\hline العبارات الصححيحة & العبارات المخطئة \\
\hline مَا أَكَثْرَ الْبَعُوْوضُ & لمِ مَذَا كَثِيْرُ بَعُوْضن \\
\hline مَمْنْنُوُعُ النَّوِْمِ هُنَا & لَالَيجُوْزُ نَوْجُ هُهنَا \\
\hline الْنقَطَعَ تَيَّارُ الْكَهْرُبَاعِ & مَافِيْ سَتْرُوُْمْ \\
\hline
\end{tabular}

Empat, Kitab al-Muhadathah al-Yaumiyah, Kitab ini ditulis oleh KH. Mohammad Marzuqi Ma'ruf bersama dengan Guru Master (GM) bahasa Inggris TMI, KH. Mohammad Fikri Husein, yang terdiri atas 70 halaman, berisikan ungkapan-ungkapan yang oleh kedua penulis disajikan dalam bentuk percakapan seharihari. Selain itu penulis juga menegaskan dalam kata pengantarnya bahwa kitab ini disusun berdasarkan hasil observasi penulis terhadap terjadinya bentuk-bentuk interferensi bahasa yang terjadi dalam hamper setiap komunikasi para santri ketika berbicara dengan mengunakan bahasa Arab dan terinterferensi oleh bahasa ibu. ${ }^{33}$

Dan lima, Kitab Ishthilahat Wa al-Asalib al-Yaumiyah, Sedangkan kitab yang terakhir yang oleh KH. Mohammad Marzuqi Ma'ruf susun merupakan kitab yang dikhususkan untuk tingkat menengah ke atas (mutaqaddim). Kitab ini dikhususkan untuk anak MA dan Universitas sederajat. Sebagaimana yang diungkapkan oleh penulisnya sebagaimana berikut:

33 Muhammad Marzuqi Ma'ruf, Muhadatsah Yaumiyah (Sumenep: TMI Press Al-Amien Prenduan, 2003), 1. 


$$
\begin{aligned}
& \text { "أن الكتاب يتضمن عددا من الاصطلاحات والأساليب العربية التي تفيد } \\
& \text { طلاب اللغة العربية والراغبين فيها، سواء في المدارس والمعاهد والجامعات. } \\
& \text { واعتمدت في اعدادها على أثوق المصيادر من المجالات والجرائد العربية. ولا } \\
& \text { أقدم أسلوبا إلا واتبعتاه ترجمة إلى اللغة الإندونيسية لتكون على متناولهم، }
\end{aligned}
$$

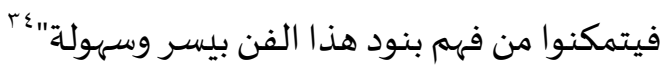

Kitab ini berisi sekitar 220 bentuk uslub dan masingmasing disertai tiga contoh. Adapun beberapa contoh isi dari kitab ini antara lain sebagaimana berikut:

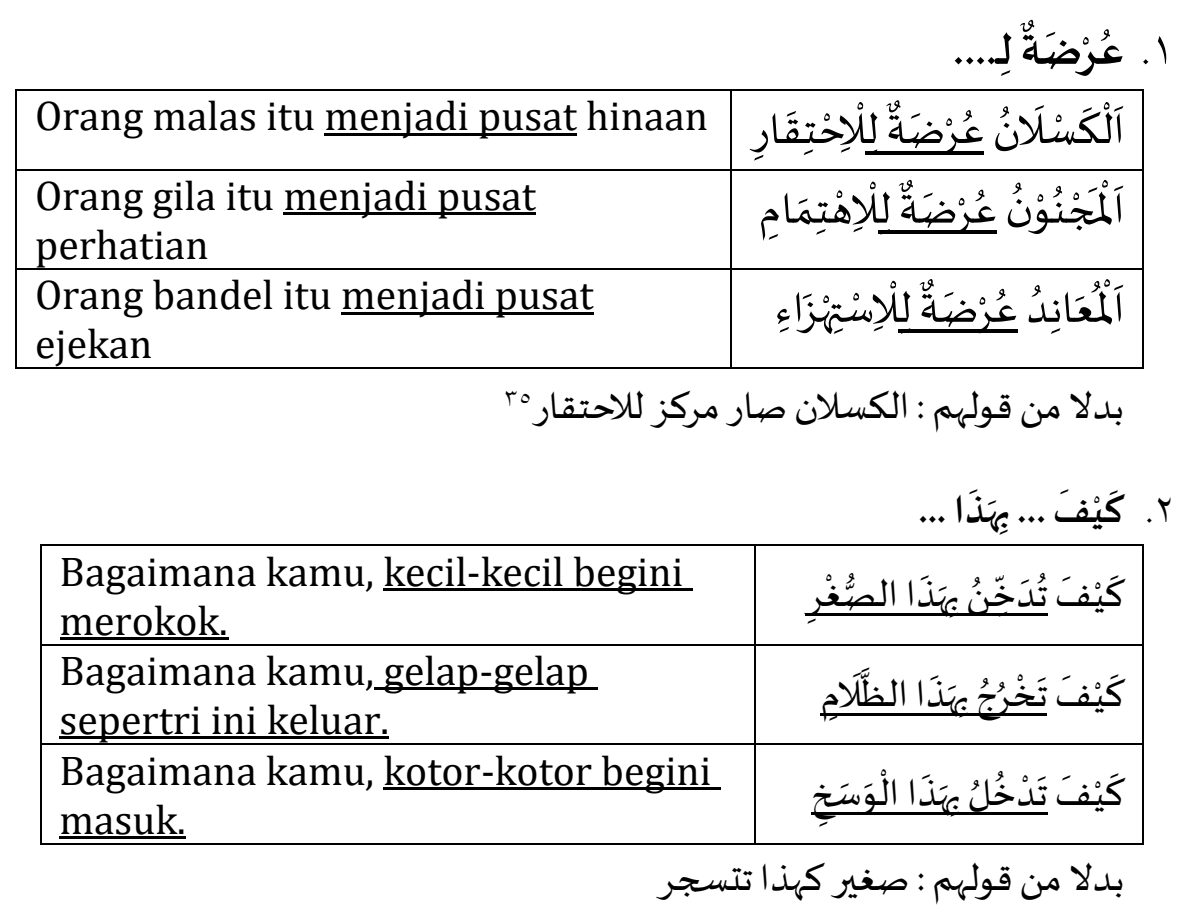

34 Muhammad Marzuqi Ma'ruf, "Ishtilahat Wa Al-Asalib Al-Yaumiyah Li AlMustawa Al-Mutaqaddim Bi Ma’had Al-Amien Al-Islami Prenduan” (n.d.): 1. 35 Ibid., 26. 


\section{Efektifitas Perbaikan Interferensi Bahasa Arab Melalui Program Islahul Akhtha'}

Pelaksanaan Kegiatan

Berdasarkan data yang peneliti dapatkan, secara umum kegiatan ishlahul Akhtha' lughawiyah berjalan sepanjang tahun, dijadwalkan berdasarkan agenda yang dibuat dan dipandu langsung oleh penanggung jawab Markaz Bahasa TMI. Secara khusus berjalan dalam dua arah, secara formal dan tidak secara formal. 36

Dalam kegiatan formal kegiatan ishlahul Akhtha' Iughawiyah ini berjalan pada setiap hari kamis pagi, mulai dari seusai shalat subuh berjamaah sampai jam 06.00 WIB, dan bertempat di Masjid Jami' Al-Amien Prenduan. Kegiatan ini dilaksanakan dengan cara membagi semua santri sesuai kelompok kelas pada kegiatan KBM pagi, dan dalam setiap kelompok terdapat satu orang guru dari Ustadz dan satu orang asisten ustadz dari Mu'allim (santri kelas V yang menjabat dalam organisasi santri), tugas ustadz adalah menyampaikan kembali ungkapan-ungkapan kalimat salah yang sudah lazim digunakan oleh para santri, kemudian diikuti dengan ungkapan islahatnya dengan baik dan benar. Para ustadz cukup menghafalkan saja dua ungkapan yang salah dan yang benar dalam bahasa Arab jauh waktu sebelum menghadiri halaqah atau kelompok acara ishlahul Akhtha' sebagaimana yang telah disediakan pihak Markaz Bahasa. Sedangkan mu'allim berperan menjadi pengganti ustadz saat para ustadz sedang berhalangan hadir, dan kewajiban

\footnotetext{
${ }^{36}$ Wawancara, Ahmad Riyadi, 08 Februari 2020.
} 
mu'allim lainnya adalah menerima setoran hafalan ungkapan ishlahul Akhtha' yang sudah diberikan. Sementara kewajiban santri adalah mengikuti seluruh intruksi yang terdapat dalam acara ini dan menyetorkannya pada mu'allim. ${ }^{37}$

Adapun ishlahul Akhtha' yang berjalan dengan tidak formal berupa perbaikan mubasyir (secara langsung) yang harus dilakukan oleh seluruh guru dan mu'alliem pada bahasa santri yang salah di lapangan. Maka dari itu, setiap ditemukannya santri yang salah dalam menggunakan bahasa Arab dan ditemukan oleh ustadz atau mu'alliem maka ia akan dipanggil sejenak untuk kemudian diperbaiki bahasa Arab yang ia gunakan.. ${ }^{38}$

Tujuan Pelaksanaan

Ada beberapa tujuan dalam pelaksanaan kegiatan ishlahul Akhtha' ini yang antara lain yaitu: a) untuk memberi tahu pada santri tentang kesalahan-kelasalahan penggunaan ungkapan yang mereka gunakan dalam bahasa Arab, b) untuk memerangi lemahnya penggunaan bahasa Arab di kalangan santri, c) untuk memperbaiki kesalahan berbahasa Arab di kalangan santri dan agar mereka tidak terperosot kembali ke dalam kesalahan yang sama pada masa selanjutnya, d) untuk membentuk lingkungan berbahasa Arab yang sesuai dengan tuntutan dan ciri has bahasa Arab dari segi morfologi, sintaksis dan bahkan budaya bahasa Arab sebagaimana yang digunakan oleh penutur aslinya. ${ }^{39}$

\section{Punishment and Reward}

\footnotetext{
37 Wawancara, Ahmad Riyadi, 08 Februari 2020.

38 Wawancara, Ahmad Riyadi, 08 Februari 2020.

39 Wawancara, Qomarul Layali, 10 Februari, 2020.
} 
Sebagaimana yang telah peneliti sampaikan di awal, bahwa TMI Al-Amien adalah lembaga yang memberikan perhatian ketat terhadap pembelajaran dan penggunaan bahasa Arab. Oleh sebab itu, bagi mereka yang melanggar undangundang penggunaan bahasa Arab terdapat beberapa bentuk punishment tersendiri yang tentunya untuk dijadikan taming dari pelanggaran santri yang sewaktu-waktu bisa terjadi.

Ada salah satu bentuk punishment atau hukuman yang memang dikhususkan atas mereka yang sengaja bermain-main dalam penggunaan bahasa Arab (sengaja menginterferensikan bahasa Arab dalam bahasa lain saat berkomunikasi secara lisan). Hal ini banyak ditemui dalam bentuk interferensi morfologi dari

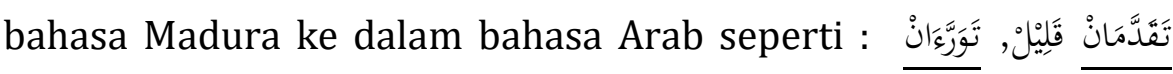

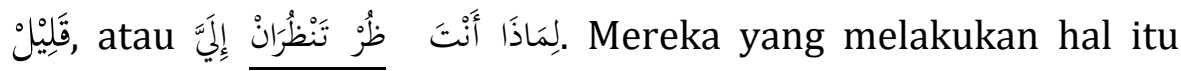
dipukul rata dianggap sebagi mufsidul lughah (perusak bahasa). ${ }^{40}$

Adapun bentuk punishment yang diberikan berupa pita pelanggaran yang berjenjang. Pita-pita itu antara lain berwarna abu-abu untuk pelanggaran pertama, pita abu-abu ini bersifat sebagai pelanggaran berbentuk peringatan. Pita kedua berwarna biru, pagi para pelanggar mufsidul lughah yang mendapatkan pita ini biasanya juga disangsi lain, yakni berdiri di depan Masjid Al-Amien beberapa saat untuk diambil i'tibar bagi yang lain. Pita ketiga berwarna hijau, baginya yang mendapatkan pita ini juga akan dibotak abri dan membuat surat pernyataan untuk tidak

\footnotetext{
${ }^{40}$ Wawancara, Miftahul Hadi, Ketua Markaz Bahasa TMI, 20 Februari 2020.
} 
mengulangi lagi. Pita keempat berwarna kuning, bagi mereka yang mendapatkan pita kuning akan dibotak bersih. Pita kelima berwarna merah, bagi mereka yang mendapatkan pita merah akan dipanggil orang tuanya untuk diyakinkan oleh pihak pesantren bahwa jika sekali lagi putranya melanggar, maka ia akan diusir tanpa penghormatan. Pita terakhir berwarna hitam, bagi mereka yang mendapatkan pita ini akan diusir tanpa penghormatan. ${ }^{41}$

Itulah bentuk-bentuk sangsi bagi mereka yang "dengan sengaja" merusak (menginterferensikan) bahasa Arab dalam bahasa lainnya. Sebaliknya pun juga demikian, ada beberapa bentuk reward atau imbalan yang diberikan atas mereka yang berprestasi serta mengharumkan bahasa Arab pondok, semisal dalam perlombaan atau hal lainnya, bagi mereka yang bias memenangkan lomba ekstrenal pesantren akan diberikan beasiswa, untuk juara I beasiswa setahun full, untuk juara II beasiswa setengah tahun, untuk juara III beasiswa satu MID. Adapun untuk mereka yang menjadi inspirasi santri secara mayoritas, mereka akan mendapatkan piagam penghargaan dari kepala sekolah.

\section{KESIMPULAN}

Terjadinya interferensi dalam komunikasi seseorang yang dalam proses belajar semua bentuk bahasa kedua termasuk bahasa Arab merupakan suatu kewajaran. Sebab adanya kedwibahasaan pada msayarakat akan menimbulkan interferensi

\footnotetext{
${ }^{41}$ Wawancara, Miftahul Hadi, Ketua Markaz Bahasa TMI, 20 Februari 2020.
} 
penyimpangan norma kebahasaan karena keakraban dua bahasa yang mereka gunakan. Hukum kemakluman itu juga wajar terjadi pada santri-santri TMI Al-Amien Prenduan yang sedang belajar bahasa Arab. Hal itu terbukti dalam penelitian ini bahwa para santri di lembaga tersebut memang telah mengalami interferensi bahasa dari sisi fonologi, morfologi dan sintaksis.

Namun TMI sebagai pondok pesantren yang telah menjunjung tinggi pembelajaran bahasa Arab sebagai bahasa komunikasi sehari-hari telah melakukan langkah yang baik dalam memperbaiki semua bentuk interferensi tersebut. Hal itu tercermin dalam peran KH. Mohammad Marzuqi Ma'ruf yang berperan penting dalam program ishalahul akhtha'. Program ini berjalan sepanjang tahun di sana. Peran beliau juga didukung kuat dengan adanya peraturan kebahasaan yang ketat yang tercermin dalam pemberian punishment dan reward. Nemun lebih dari pada itu sebab beliau adalah sosok yang produktif dalam berkarya, dan karya-karyanya telah dijadikan bahan utama dalam program ishalahul akhtha'ini.

\section{DAFTAR PUSTAKA}

Administrasi, Tim. "SAS Sistem Administrasi Santri TMI ALAmien Prenduan," n.d.

Agustia, Km Tri Surisna. "Interferensi Bahasa Indonesia Terhadap Pemakaian Bahasa Inggris Pada Siswa Kelas VIII Sekolah Menengah Pertama." Litera 3o (2017).

Al-Khuli, Ali Mohammad. Madkhal Ila 'Ilmi Al-Lughah. Ordon: Dar al Falah, 1993.

Amatullah, Muna Nabila, and Lady Farah Aziza. "Interferensi Bahasa Indonesia Dalam Bahasa Arab: Kasus Pada Kesalahan Berbahasa Siswa Kelas X Man 1 Sragen." ALSUNIYAT: Jurnal 
Penelitian Bahasa, Sastra, dan Budaya Arab 3, no. 1 (2020): 47-60.

Arifah, Zaidatul. "Interferensi Dan Integrasi Kata-Kata Daerah Dan Asing Dalam Novel 'Dian Yang Tak Kunjung Padam.'” Metalingua 5, no. Bahasa dan Sasra Indonesia (2020).

Bundiarti, Any. "Interferensi Bahasa Indonesia Ke Dalam Bahasa Inggris Pada Abstrak Jurnal Ilmiah." Jurnal Bahasa dan Seni 41, no. 1 (2013).

Chaer, Abdul \& Loenie Agustiana. Sosiolinguistik Perkenalan Awal. Jakarta: Rineka Cipta, 2010.

Dimyathi, Mohammad Afifudin. Madkhal Ila IImi Al-Lughah. Malang: Makabah Lisan Arabi, 2016.

Fauziati, Endang. "Interferensi Gramatikal Bahasa Indonesia Dalam Bahasa Inggris: Kasus Pada Buku LKS Bahasa Inggris Untuk SLTP Di Surakarta." Jurnal Penelitian Humaniora 17, no. 2 (2016).

J Moleng, Lexi. Metodologi Penelitian Kualitatif. Bandung: Remaja Rosda Karya, 2009.

Ma'ruf, Muhammad Marzuqi. Ishlah Al-Akhtha' Fi Usbu' AlLughah. Sumenep: Markas Bahasa Pondok Pesantren AlAmien Prenduan, 2019.

- - - Ishthilahat Al-Saya'íah Li Al-Mustawa Al-Mutawassith, n.d.

- - - Ishthilahat Wa Ishlah Al-Akhtha' Li Al-Mustawa Al Mutawassith Bi Ma'hadi Al-Amien Al-Islami Prenduan, n.d.

-_- " "Ishtilahat Wa Al-Asalib Al-Yaumiyah Li Al-Mustawa AlMutaqaddim Bi Ma'had Al-Amien Al-Islami Prenduan" (n.d.).

- - C. Muhadatsah Yaumiyah. Sumenep: TMI Press Al-Amien Prenduan, 2003.

Makinuddin, Mohammad. "Al-Biah Al-Lughawiyah Wa Taudhzifiha Fi Ta'lim Al-Lughah Al-Arabiyah." UIN Maulana Malik Ibrahim Malang, 2017.

Mustofa, Muhamad Arif. "Interferensi Bahasa Indonesia Terhadap Bahasa Arab (Analisis Interferensi Dalam Pembelajaran Maharah Kalam)." Jurnal An-Nabighoh 20, no. 2 (2018): 139-160.

Rusli, Muhammad. Pedoman Praktis Membuat Proposal Dan Laporan Penelitian Lapangan. Sumenep: LP3M Paramadani, 
2013.

Suindratini, and Dkk. "Interferensi Bahasa Bali Dan Bahasa Asing Dalam Cerita Lisan Bahasa Indonesia Kelas VII Siswa SMP Negeri 10 Denpasar." Jurnal Program Pascasarjana Universitas Pendidikan Ghanesha Program Pendidikan Ghanesa Program Studi Pendidikan dan Sastra Indonesia 2 (2013).

Warkat, Tim Penyusun. Jurnal Informasi Tahunan Pondok Pesantren Al-Amien Prenduan Provinsi Jawa Timur. Sumenep, 2016.

Zuhdi, Halimi. Al-Biah Al-Arabiyah: Takwinuha Wa Dauriha Fi Iktisabi Al-Arabiyah. Malang: UIN Maliki Press, 2017.

Zuliana, Emi. "Analisis Campur Kode (Mixing Code) Dan Alih Kode (Code Swiching) Dalam Percakapan Bahasa Anak, Studi Pada Mahasiswa Prodi Pendidikan Bahasa Arab IAIM NU Metro Lampung." IAIM NU(n.d.). 
Abdul Kirom | MAHAROT Vol. 4, No. 2, 2020 